\title{
Basic sciences and nursing
}

\author{
Evelin Capellari Cárnio
}

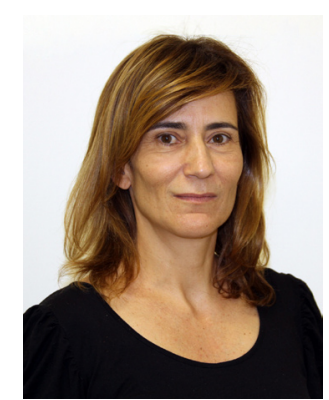

'Basic sciences' is a term that refers to studies supporting the range of professional education in different knowledge areas.

Basic research, whether in the biological, exact or human area, supports professional practice as well as applied research, even if in the long term. The list of Nobel Prize winners in Medicine and Physiology in recent decades reveals that various scientists have received this award as a result of basic discoveries, which were later incorporated into clinical practice ${ }^{(1)}$. Pure science also entails esthetic, spiritual and artistic aspects for human beings, as this research grants us the possibility of small advances in knowledge about our interior world and the world that surrounds us $^{(1)}$. In a more pragmatic view, the importance of basic science in comprehensive higher education is highlighted. The people involved in these students' education should engage in challenging problems, in contact with other researchers and with an open mind to receive and process new information, so as to improve teaching quality. In this sense, students who get involved in projects related to basic sciences learn to use the scientific method, stimulated by the mere pleasure of knowledge production, without any concern with its direct application. Thus, the University enhances the encounter of people willing to learn how to learn, linking education with knowledge production, leading to inevitable improvements in teaching quality. Therefore, Nursing, a profession with such a comprehensive knowledge area, cannot do without basic sciences.

In nursing, since the 1960's, studies originating in areas like sociology, anthropology and psychology have been emphasized to the detriment of other basic sciences from the biological and exact areas ${ }^{(2)}$. One can depart from the premise that a scientific legitimation process of the profession has occurred, in the attempt to gain distance from the medical area and, consequently, get involved in other exploratory, social, theoretical and historical research models. The nature of nursing practice, which often demands interventions supported by biomedical knowledge, however, has made us attempt to go beyond basic experimental research in the care area(3), leading to a substantial growth in practice, creating perspectives for the profession in multiple directions.

Skilled nurses in experimental research development, based on biomedical and exact scientific knowledge, can offer important contributions in different application areas, enhancing the intersection between patients' physiopathological and psychological states.

Finally, it should be reminded that there are many people, including politicians, journalists and even scientists, who believe that, in a country like Brazil, or in a profession like nursing, pure science should not be encouraged, as a direct application does not always take place. I believe, however, that if nursing wants to constantly improve its professional practice, multidisciplinary research needs to be valued, whose development is marked by flexibility and cooperation with scientists and/or professionals from other areas, broadly comprising care, teaching and research. 


\section{References}

1. Ziman J. A força do conhecimento. São Paulo: Editora Itatiaia/EdUSP; 1981.

2. Almeida MCP. A construção do saber na enfermagem: evolução histórica. $3^{\circ}$ Seminário Nacional de Pesquisa em Enfermagem; 1984 abril 3-6; Florianópolis, SC, Brasil. Florianópolis: UFSC; 1984. p. 58-77.

3. D'Antonio P. Toward a history of research in nursing. Nurs Res 1997 Mar-Apr;46(2):105-10.

Evelin Capellari Cárnio is Associate Editor of the Revista Latino-Americana de Enfermagem, and Associate Professor of the Escola de Enfermagem de Ribeirão Preto, Universidade de São Paulo, WHO Collaborating Centre for Nursing Research Development, SP, Brazil. E-mail: carnioec@eerp.usp.br. 